\title{
Counseling Acceptance Skills School Counselor In Individual Counseling
}

\author{
Mirda Yolanda*), Fadhillah Yusri, Junaidi \\ Institut Agama Islam Negeri Bukittinggi, West Sumatra, Indonesia. \\ *)E-mail: yolandamirda@gmail.com
}

\begin{abstract}
The purpose of this study is that researchers want to look at counselee acceptance skills in individual counseling by guidance and counseling teachers in MTsN 10 Agam. This type of research is descriptive qualitative field research. The key informants of this study were 1 guidance and counseling teacher plus a supporting informant of 7 students who had participated in individual counseling using the snowball method, which is a method for identifying, selecting and taking samples in a network or continuous chain of relationships. The information obtained will be developed to the point of saturation so that the longer the more information obtained. Based on the results of research and discussion it can be concluded that as a strategy for counselee acceptance skills by counseling teachers in individual counseling, counseling teachers assume counselee is the closest person, can accept counselees openly, guiding sincerely or voluntarily, sincerity, and loving, keep secrets counselee, not discriminating counselee, and love counseling.
\end{abstract}

Keywords: Acceptance Skills; Teacher; Guidance and Counseling

\section{Abstrak}

Tujuan penelitian ini peneliti ingin melihat keterampilan penerimaan konseli dalam konseling perorangan oleh guru bimbingan dan konseling di MTsN 10 Agam. Jenis penelitian ini adalah penelitian lapangan bersifat deskriptif kualitatif. Informan kunci dari penelitian ini adalah 1 orang guru bimbingan dan konseling di tambah dengan informan pendukung 7 orang siswa yang telah mengikuti konseling perorangan dengan menggunakan metode snowball, yaitu suatu metode untuk mengidentifikasi, memilih dan mengambil sampel dalam suatu jaringan atau rantai hubungan yang menerus. Informasi-informasi yang didapat akan dikembangkan sampai pada titik kejenuhan sehingga semakin lama maka semakin banyak informasi yang diperoleh. Berdasarkan hasil penelitian dan pembahasan dapat diambil kesimpulan bahwa sebagai strategi keterampilan penerimaan konseli oleh guru BK dalam konseling perorangan, guru BK menganggap konseli adalah orang terdekatnya, dapat menerima konseli dengan terbuka, membimbing dengan ikhlas atau sukarela, ketulusan, dan penuh kasih sayang, menjaga rahasia konseli, tidak membeda-bedakan konseli, dan menyayangi konseling.

Kata Kunci: Keterampilan Penerimaan, Guru; Bimbingan dan Konseling. 


\section{PENDAHULUAN}

Berbagai permasalahan sangat mungkin ditemukan dalam perkembangan dan proses kehidupan manusia. Baik oleh individu secara perorangan maupun secara kelompok, baik terlihat secara langsung ataupun tidak langsung. Masalah merupakan sesuatu atau persoalan yang harus diselesaikan atau dipecahkan. Masalah ini dapat terjadi karena ketidak mampuan individu tersebut dalam memenuhi harapan atau kesenjangan antara harapan dan kenyataan. Apabila masalah tersebut dibiarkan berkembang akan berakibat buruk terhadap individu itu sendiri maupun terhadap orang lain.

Semua orang tentunya memiliki masalah, sebab mustahil orang hidup tidak mempunyai permasalahan. Sebagian besar orang menghadapi masalah dengan berdiam diri saja. Padahal dengan berdiam diri tidak dapat menyelesaikan masalah. Kadar permasalahan dalam hidup manusia berbeda-beda. Namun kebanyakan permasalahan manusia hampirsama.

Begitupun di jenjang pendidikan, siswa juga banyak mengalami permasalahan. Permasalahan yang dialami para siswa disekolah sering kali tidak dapat dihindari.Meski dengan pengajaran yang baik sekalipun. Hal ini terlebih lagi di sebabkan karena sumber-sumber permasalahan siswa banyak yang terletak di luar sekolah. Dalam kaitan itu, permasalahan siswa tidak boleh dibiarkan begitu saja. Apabila misi sekolah adalah menyediakan pelayanan yang luas untuk secara efektif membantu siswa mencapai tujuan-tujuan perkembangan dan mengatasi permasalahannya, maka segenap kegiatan dan kemudahan yang diselenggarakan sekolah perlu di arahkan ke samping kegiatan pengajaran. Dalam tugas pelayanan yang luas, bimbingan dan konseling disekolah adalah pelayanan untuk semua murid yang mengacu pada keseluruhan perkembangan mereka.

Alquran surah Al-'Ashr ayat 1 sampai 3 Yang artinya : "Demi masa. Sesungguhnya manusia itu benar-benar berada dalam kerugian, kecuali orangorang yang beriman dan mengerjakan amal saleh dan saling nasehat-menasehati supaya menaati kebenaran dan nasihat-menasehati supaya menetapi kesabaran" (Departemen Agama Republik Indonesia, 1989). Berdasarkan ayat ini dapat dilihat bahwa saling menasihati untuk mentaati kebenaran ini merupakan Sesuatu yang sangat penting. Karena melaksanakan kebenaran itu sulit dan hambatannya banyak seperti hawa nafsu, logika kepentingan, pola pikir lingkungan, kezaliman orang-orang yang zalim, dan penganiayaan para penyeleweng. Tawaashi adalah mengingatkan, memberi semangat, menyadarkan betapa dekatnya tujuan dan sasaran yang hendak dicapai, dan mengingatkan akan perlunya persaudaraan di dalam memikul beban dan mengemban amanat. Maka dari itu layanan bimbingan dan konseling sangat penting bagi kehidupuan manusia, khususnya dalam proses pendidikan dan pengajaran karena kebutuhan manusia secara individu akan bantuan (Quthb, 2001).

Layanan bimbingan dan konseling sangat dibutuhkan disekolah karena layanan bimbingan dan konseling merupakan usaha untuk membantu siswa agar dapat memahami dirinya, yaitu baik potensi maupun kelemahan-kelemahan dirinnya. Jika siswa tersebut dapat mengetahui dan memahami potensi maupun kelemahannya dengan baik, maka siswa tersebut tentu mempunyai rencana untuk 
mengarahkan dirinya kearah realisasi diri yang mempertimbangkan kenyataan sosial dan lingkungan lainnya (Willis, 2011).

Konselor adalah pendidik, karena itu konselor harus berkompeten sebagai pendidik. Konselor adalah seorang profesional, karena itu layanan bimbingan dan konseling harus diatur dan didasarkan kepada regulasi perilaku profesional, yaitu Kode Etik (Yusri, 2019). Pada pelayanan bimbingan dan konseling, konselor dapat menggunakan konseling perorangan sebagai bantuan yang diberikan konselor kepada konseli dengan tujuan berkembangnya potensi konseli, mampu mengatasi masalah sendiri, dan dapat menyesuaikan diri secara positif. Tidak hanya konseling perorangan saja, namun layanan bimbingan dan konseling lainnya juga dapat saling berkaitan dalam proses bantuan yang diberikan konselor tersebut. Agar konseling perorangan ini dapat berjalan dengan baik dan mendapatkan hasil yang dikehendaki dalam pemecahan masalah konseli, maka seorang konselor harus menguasai teknik-teknik dalam konseling perorangan serta memahami keterampilan-keterampilan yang harus dimiliki oleh seorang konselor.

Pada setiap tahapan proses konseling seorang konselor memerlukan penerapan keterampilan-keterampilan tertentu. Tujuannya agar proses konseling dapat berjalan secara lancar,efektif, dan efesien. Konselor harus mampu mengimplementasikan keterampilan-keterampilan yang seharusnya dimiliki oleh seorang konselor tersebut. Konselor yang terampil adalah konselor yang mengetahui serta memahami sejumlah keterampilan tertentu dan mampu mengimplementasikannya dalam proses konseling. Salah satu keterampilan yang sangat dibutuhkan dalam konseling yaitu keterampilan penerimaan. Karena dengan adanya keterampilan penerimaan ini konseli akan lebih dapat terbuka kepada konselor dalam menceritakan segala hal yang berkaitan dengan dirinya ataupun yang dialaminya. Maka dari itu keterampilan konselor yang akan difokuskan dalam penelitian ini adalah Keterampilan Penerimaan Konseli oleh Guru Bimbingan dan Konseling dalam konseling perorangan.

Istilah penerimaan (acceptance) ekuivalen pengertiannya dengan penghargaan positif (positive regard) sebagai lebih mengandung sikap dan agak berbeda dengan "memperhatikan"/"peduli" (respect) yang lebih merupakan aktivitas. Penerimaan sebagai salah satu sikap dasar konselor mengacu pada kesediaan konselor memiliki penghargaan tanpa menggunakan standar ukuran atau persyaratan tertentu terhadap individu sebagai manusia atau pribadi secara utuh, berarti konselor menerima setiap individu konseli yang datang kepadannya, dalam konseling tanpa menilai aspek-aspek pribadinya yang "lemah" ataupun yang "kuat". Dengan kata lain, konselor mempunyai penerimaan "apa adanya", tidak mengandung kesetujuan atau ketaksetujuan terhadap aspek-aspek pribadi individu (Mappiare, 2008).

Jelas bahwa melalui penerimaan, konselor menyediakan pertemuan konseling sebagai suatu tempat para konseli dapat merasa aman, "bebas", dan leluasa mengeksplorasi dunia "batin" mereka.Keadaan konseli yang seperti ini secara nyata ditandai adanya peningkatan kesukaan dan kesediaan lebih terlibat dalam proses konseling, tidak sungkan menemui konselor, dan meningkatkan kesediaan mempercakapkan hal-hal rahasia pada dirinya. Hal ini akan benar- 
benar terjadi jika konselor menerima mereka secara sungguh-sungguh dan konseli mengalami penerimaan konselor. Jadi, penerimaan merupakan komponen penting dari penghargaan konselor terhadap konseli, dan merupakan dasar proses konseling secara keseluruhan (Mappiare, 2008).

Fenomena yang peneliti temukan melalui wawancara dan observasi dengan guru bimbingan dan konseling di MTsN 10 Agam.Dari hasil observasi terdapat beberapa hal yang terlihat terutama untuk teknik membangun hubungan dengan konseli seperti keterampilan penerimaan, yaitu adaguru bimbingan dan konseling yang kurang dalam melaksanakaan tahap-tahap proses konseling. Misalnya kurang menerapkan tahapan persiapan dalam menerima konseli dengan langsung saja menuju pada isi atau topik persoalan yang akan dibicarakan oleh konseli.Sehingga membuat konseli merasa terkejut dan belum siap dalam melakukan proses konseling. Waktu yang dimiliki guru bimbingan dan konseling juga kurang cukup banyak untuk melakukan layanan bimbingan dan konseling dikarenakan bentrok dengan jadwal mata pelajaran lain. Sarana dan prasarana yang dibutuhkan dalam proses konseling juga kurang tersedia yang membuat guru bimbingan dan konseling sulit dalam melakukan proses bimbingan dan konseling. Sehingga dari beberapa penjelasan tersebut membuat konseling kurang berjalan dengan efektif terutama pada tahap penerimaan konseli.

Pada studi pendahuluan didapat data bahwa keterampilan yang dimiliki oleh guru bimbingan dan konseling menjadi pendengar yang baik, mampu memberikan informasi yang dibutuhkan konseli, menerima konseli apa adanya, menjadi pendengar yang baik, dapat merahasiakan segala data dan keterangan konseli yang tidak boleh dan tidak layak diketahui orang lain.Keterampilan guru bimbingan dan konseling sangatlah penting menurut guru bimbingan dan konseling, karena dengan adanya keterampilan tersebut konseliakan lebih dapat terbuka serta memiliki rasa nyaman dan percaya terhadap konselornya. Keterampilan seorang konselor atau guru bimbingan dan konseling tersebut tentunya didapatkan dengan latihan serta seberapa sering proses konseling individu tersebut dilakukan. Tidak lupa pula bahwa guru bimbingan dan konseling tersebut harus menanamkan serta melakukan keterampilan tersebut dalam kehidupan sehari-harinya agar dapat melatih kemampuan seorang konselor tersebut.

Kemudian temuan studi pendahuluan lainnya menghasilkan temuan bahwa masih banyak siswa yang takut untuk melakukan konseling perorangan, dikarenakan siswa menganggap bimbingan dan konseling merupakan tempat penyelesaian pelanggaran yang dilakukan oleh siswa.Ada beberapa siswa yang berpendapat bahwa guru bimbingan dan konseling kurang hangat dalam mendekati siswa.Maka dari itu siswa kurang banyak berinteraksi dengan guru bimbingan dan konseling.

Penjelasan diatas menggugah penulis untuk mengetahui secara lebih lanjut mengenai kemampuan penerimaan konseli oleh guru bimbingan dan konseling di MTsN 10 Agam, sebagai tolak ukur kesiapan sebelum praktik sebagai Guru BK nantinya. 


\section{METODE}

Untuk memperoleh data yang di perlukan, dalam penelitian ini penulis melakukan penelitian lapangan bersifat deskriptif kualitatif. Deskriptif kualitatif yaitu dengan menggambarkan kejadian yang terjadi di lapangan. Sesuai dengan data dan informasi atau penelitian yang berusaha untuk mengumpulkan datadata, menyajikan data, menganalisis data menggambarkan pemecahan masalah yang ada (Margono, 2007).

Metode penelitian kualitatif merupakan metode penelitian yang memiliki karakteristik berupa analisis naratif terhadap informasi-informasi yang dikumpulkan dalam proses pengumpulan data (Hanurawan, 2016). Penelitian kualitatif juga merupakan sebagai penelitian yang menghasilkan data deskriptif mengenai kata-kata lisan maupun tertulis, dan tingkah laku yang dapat diamati dari orang-orang yang diteliti (Suyanto \& Sutinah, 2005). Penelitian deskriptif juga merupakan penelitian yang dilakukan terhadap kejadian yang sedang atau sudah terjadi. Peneliti mendeskripsikan atau memusatkan perhartian kepada masalahmasalah aktual yang sedang atau sudah terjadi dan data diinginkan apa adanya tanpa manipulasi. Dalam hal ini peneliti menggambarkan tentang keterampilan penerimaan konseli dalam konseling perorangan oleh guru bimbingan dan konseling.

Teknik pengumpulan data maka penulis menggunakan instrument diantaranya : (1) Wawancara, (2) Observasi, (3) Dokumentasi .Teknik analisis data meliputi aktifitas diantaranya : (1) Data reduction (reduksi data), , (2) Data display (penyajian data), (3) Conclusion drawing/ verification (penarikan kesimpulan dan verifikasi). Dan teknik keabsahan data penulis menggunakan triangulasi data menggali kebenaran informasi tertentu melalui berbagai sumber memperoleh data (Gunawan, 2014).

\section{HASIL PENELITIAN DAN PEMBAHASAN}

\section{Memperhatikan}

Kemampuan memperhatikan ini memerlukan keterampilan dalam mendengar dan mengamati untuk dapat mengetahui dan mengerti inti dari isi dan suasana perasaan bagaimana yang di ungkapkan konseli baik dalam katakata maupun isyarat. Berdasarkan hasil wawancara yang peneliti lakukan dengan guru bimbingan dan konseling tentang memperhatikan konseli yaitu :

"Pertama kali yang dilakukan tentunya dengan membangun kesan pertama atau pandangan pertama yang mengesankan diiringi dengan wajah yang ceria ketika ibu sudah mengetahui identitas anak tersebut, maka ibu akan kemukakan pertanyaan apa yang bisa ibu bantu. Menciptakan rasa nyaman, tidak berbahasa formal untuk menimbulkan suasana yang santai, berbasa-basi sebelum masuk ke inti permasalahan, meyakinkan bahwa hal yang akan dibicarakan hanya kita berdua (konselor dan konseli) yang tahu. Kita dapat membuat anak nyaman dan terbuka." 
Seiring dengan itu peneliti juga melakukan wawancara dengan konseli yang menyatakan bahwa :

"Cara guru bimbingan dan konseling menerima saya dengan baik. Guru BK menerima saya dengan mempersilahkan saya duduk di kursi yang berada di depan meja guru BK. Sehingga saya tidak merasakan sesuatu hal yang janggal." (F)

"Berhubungan dengan itu saya mengatakan ketika guru BK menerima saya, guru BK terlebih dahulu melihat dan memperhatikan saya kemudian tersenyum dan memperlihatkan wajah yang ceria." (Z)

"Cara guru BK menerima siswa terlihat dari bagaimana situasi dan kondisi. Saya bisa mengetahui dengan memperhatikan kondisi lingkngan sekitar, sehingga saya paham apa yang sedang terjadi. Apakah guru bimbingan dan konseling sedang baik atau marah." (P)

"Guru BK dalam menerima siswa secara baik sehingga saya tidak takut bertemu dengan guru bimbingan dan konseling." (R)

"Guru BK menerima terkadang dengan raut wajah yang terkadang ditakuti sehingga menimbulkan rasa takut." (T)

"Guru BK dalam menerima siswa yang tidak memiliki persoalan dengan baik dan memberikan senyum yang manis." (S)

"Guru BK menerima saya dengan kondisi yang wajar sehingga saya tidak takut untuk bertemu guru bimbingan dan konseling." (D)

Berdasarkan hasil observasi yang peneliti lakukan pada tanggal 18 Februari 2020 di MTs N 10 Agam tepatnya di dalam ruang majelis guru ketika adanya konseli untuk mengikuti konseling perorangan, guru bimbingan dan konseling mempersilahkan konseli untuk duduk. Guru bimbingan dan konseling juga memperhatikan konseli dengan pandangan yang fokus kepada konseli.

Berdasarkan hasil wawancara dan obervasi di atas diketahui bahwa guru bimbingan dan konseling memperhatikan konseli yang datang untuk mengikuti konseling perorangan. Guru bimbingan dan konseling menatap konseli dengan lembut terlihat dari paras wajah guru bimbingan dan konseling yang tersenyum kepada konseli, saat konseli berbicara guru bimbingan dan konseling memperhatikan raut wajah konseli. sekali-sekali terlihat guru bimbingan dan konseling mengalihkan pandangan dari konseli dengan melihat ke samping kiri dan kanan untuk memperhatikan keadaan sekitar kemudian kembali memperhatikan konseli dengan menatap mata konseli. terlihat juga beberapa kali guru bimbingan dan konseling mengerutkan dahi dan menganggukkan kepada dengan lambat. Terkadang guru bimbingan dan konseling juga memberikan senyuman kepada konseli.

Memberikan perhatian terhadap konseli juga harus dipersiapkan. Penyiapan penerimaan konseli tidak hanya menyiapkan sarana yang ada di tempat konseling, namun juga meliputi usaha mengajak mereka untuk memanfaatkan konseling, pemberian informasi kepada mereka tentang kesediaan konselor membantu mereka, dan mendorong mereka menggunakan bantuan tersebut. Penyiapan konteks meliputi pengaturan meja, kursi, dekorasi, dan 
pengaturan ruangan tempat pertemuan konseling. Persiapan konselor meliputi meninjau apa yang telah ia ketahui tentang konseli, tujuan bantuan, dan rileksasi (Taufik, 2012).

\section{Mendengarkan}

Keterampilan mendengarkan adalah kemampuan konselor untuk menyimak atau memperhatikan penuturan konseli selama proses konseling berlangsung. Konselor harus bisa menjadi pendengar yang baik selama sesi konseling berlangsung. Berdasarkan hasil wawancara yang peneliti lakukan dengan guru bimbingan dan konseling tentang mendengarkan konseli yaitu :

"Ibu akan mendengarkan konseli mulai dari awal konseling perorangan hingga berakhirnya konseling perorangan. Konseli yang sudah mulai menjelaskan atau mengutarakan isi hatinya maka ibu akan dengarkan, kemudian ibu tangkap atau analisasis setiap yang diucapkan konseli dan mencoba untuk mengkonfrontasikan kemudian ibu juga akan mempersiapkan catatan-catatan kecil dalam proses konseling tersebut. Tentunya ibu tetap menjadikan konseli sebagai prioritas. Ibu tetap akan fokus pada konseli dengan menahan atau mengabaikan sementara gangguan dari luar. Akan tetapi bila ada hal yang mendesak seperti ibu dipanggil oleh guru yang lain maka ibu masih bisa tetap fokus kepada konseli tanpa mengabaikan konseli. Ibu akan tetap mendengarkan dan menganalisis setiap yang diutarakan konseli.

Seiring dengan itu peneliti juga melakukan wawancara dengan konseli yang menyatakan bahwa :

"Guru BK mendengarkan saya bila saya mengatakan atau berbicara kepada guru $B K . "(\mathbf{F})$

"Guru BK bila berbicara dengan siswa dan apa yang diutarakan siswa, guru bimbingan dan konseling berserta siswa saling mendengarkan satu sama lain." (Z) "Guru BK menerima serta mendengarkan siswa-siswanya." (P)

"Saya merasa terkadang tidak terlalu diperhatikan guru BK, karena guru BK sering diganggu oleh pihak dari luar." (R)

"Guru BK sangat asik untuk didekati bisa berbagi suka dan dukanya." (T)

"saya merasa guru BK baik dalam mendengarkan apa yang disampaikan oleh saya kepada guru BK." (S)

"Sudah merasa baik dengan guru bimbingan dan konseling karena guru BK mendengarkan dengan baik apa yang saya sampaikan." (D)

Berdasarkan hasil observasi yang peneliti lakukan pada tanggal 18 Februari 2020 di MTs N 10 Agam tepatnya di dalam ruang majelis guru ketika adanya konseli untuk mengikuti konseling perorangan, guru bimbingan dan konseling mendengarkan pernyataan yang disampaikan oleh konseli sehingga guru bimbingan dan konseling dapat memberikan respon kepada konseli. Berdasarkan hasil wawancara dan observasi di atas dapat diketahui guru bimbingan dan 
konseling mendengarkan setiap pernyataan yang diutarakan oleh konseli. Guru bimbingan dan konseling terlihat memberikan dorongan minimal dengan mengatakan "ya, lalu, kemudian" sehingga konseli terlihat tidak banyak diam melainkan konseli terdorong untuk terus berbicara. Proses konseling yang berlangsung guru bimbingan dan konseling juga disapa oleh guru mata pelajaran lain.

Semua orang tidak terkecuali konseli, ingin diperhatikan dan didengarkan. Kebutuhan untuk didengarkan dan diperhatikan akan menonjol pada diri orang yang sedang mengalami masalah. Dapat diibaratkan orang sedang mengalami masalah seperti orang hanyut mendapatkan sepotong kayu untuk dipegang. Bentuk nyata kegiatan konselor yang memperhatikan dan mendengarkan ini ialah dengan cara memahami dan merespon pembicaraannya dengan tepat (Taufik, 2012).

\section{Menunda Pendapat yang Mengkritik}

Berkaitan dengan ini, konselor hendaklah menunjukkan keobjektifannya. Konselor dapat menerima kesalahan-kesalahan atau kekeliruan sebagai manusia dapat saja terjadi. Apabila konselor melihat kesenjangan yang perlu disampaikan untuk segera diubah dan diperhatikan, maka tidaklah perlu segera disampaikan. Penyampaianya perlu menunggu waktu yang tepat. Berdasarkan hasil wawancara yang peneliti lakukan dengan guru bimbingan dan konseling tentang menunda pendapat yang mengkritik:

"Terlebih dahulu ibu akan memanggil konseli tersebut apabila konseli itu tidak memiliki inisiatif atau kemauan sendiri untuk menemui ibu. Tentunya ibu ingin konseli secara sadar untuk mengungkapkan isi hatinya. Ibu akan berusaha menganalisisinya. Apabila ibu menemukan sesuatu hal yang janggal atau tidak sesuai dengan yang ibu fikirkan maka ibu akan mencoba atau berusaha membuat konseli berfikir dan sadar dalam persoalan konseli tersebut dan mengajak konseli untuk berfikir apakah yang dilakukan konseli itu baik atau buruk."

Seiring dengan itu penulis juga melakukan wawancara dengan konseli yang menyatakan bahwa :

"Respon guru BK terhadapnya biasa-biasa saja karena saya belum pernah memiliki persoalan yang serius di sekolah." (F)

"Respon guru BK sama dengan respon guru mata pelajaran lainnya." (Z)

"Respon guru bimbingan dan konseling peduli dengan siswanya dan persoalan yang ada di sekolah tersebut." (P)

"Respon guru BK ramah namun terkadang wajah guru BK membuat saya takut. Seperti jika saya sedih guru bimbingan dan konseling akan mengusap saya. Bila saya bahagia maka kami akan tertawa bersama." (R)

"Guru BK akan memberikan kita respon yang baik ketika kita bertanya dengan baik dan ketika guru BK bercanda maka kita juga bisa bercanda dengan BK tersebut." (T) 
"Guru BK ramah dan nyaman untuk bersama dengan guru BK." (S)

"Respon yang diberikan guru BK sesuai dengan persoalan yang dialami. Apabila saya melakukan kesalahan maka guru BK akan menegur dengan baik." (D)

Berdasarkan hasil observasi yang peneliti laukukan pada tanggal 20 Februari 2020 di MTsN 10 Agam tepatnya di dalam ruang majelis guru ketika konseli mengikuti konseling perorangan, guru bimbingan dan konseling tidak langsung memberikan kritikan kepada konseli saat menemui kejanggalan dari pernyataan konseli. Guru bimbingan dan konseling dapat menerima kejanggalan yang dirasakannya terhadap yang disampaikan oleh konseli. Guru bimbingan dan konseling memberikan dorongan minimal dan pertanyaan terbuka terhadap konseli agar konseli dapat terbuka dan mengutarakan isi hatinya.

Berdasarkan hasil wawancara dan observasi di atas dapat diketahui meski pada awalnya guru bimbingan dan konseling melihat ada beberapa hal pada diri konseli terdapat kesenjangan atau kekeliruan yang perlu disampaikan untuk segera diubah dan diperbaikinya, maka tidaklah perlu segera disampaikan. Penyampainya perlu menunggu waktu yang tepat. Keadaan ini lebih disebabkan bahwa kebanyakan orang agak sensitif untuk dikritik. Kritikan yang disampaikan tidak pada waktu yang tepat meski itu positif dapat melenceng dari sasaran yang diinginkan (Taufik, 2012).

\section{Berkomunikasi}

Komunikasi konselor yang terstruktur secara sistematis dan jelas akan menumbuhkan kepercayaan konseli untuk menyampaikan sesuatu yang sedang dirasakan dan dialaminya, namun hendaklah diiringi dengan pemahaman konselor. Berdasarkan hasil wawancara yang peneliti lakukan dengan guru bimbingan dan konseling tentang berkomunikasi :

"Ibu akan menggunakan komunikasi secara langsung dengan konseli dalam suasana yang tidak terlalu formal, santai, nyaman, dan mengajak konseli untuk terbuka. Anak yang tidak ingin menemui ibu secara langsung maka ibu menerapkan untuk menulis diari. Diari itu nantinya akan ibu jadikan sebagai perantara berkomunikasi antara ibu dan konseli. Ibu juga akan memberikan tanggapan di dalam diari yang telah dibuat oleh konseli tersebut. "

Seiring dengan itu peneliti juga melakukan wawancara dengan konseli yang menyatakan bahwa :

"Intonasi komunikasi guru BK dapat berubah-rubah. Terkadang tinggi terkadang lembut. Saat berbicara guru BK terkadang menganggukkan kepala dan tersenyum." (F)

"Intonasi guru BK bisa berubah-rubah sesuai kondisi. Terkadang guru BK bisa marah bila ada siswa yang tidak bisa berubah. Guru BK terkadang terlihat mengkerutkan dahinya saat marah." (Z)

"Intonasi guru BK terkadang lemah lembut, dan ada pula saatnya tinggi ketika marah." (P) 
"Menemui guru BK terkadang tidak dari kemauan sendiri melainkan sering diminta oleh wali kelasnya. Maka bila saat itu guru BK akan bercanda kepada saya kenapa saya bisa diminta oleh wali kelas untuk menemui guru BK. saya akan melihat guru BK yang tertawa saat bercanda." (R)

"Jika guru BK marah maka guru BK dapat mengeluarkan kata-kata yang dapat membuat kita sadar tanpa perlu menggunakan suara yang keras kepada kita." (T)

"Guru BK tegas dalam menyikapi suatu hal." (S)

"Bila marah intonasi guru bimbingan dan konseling akan sedikit lantang. Namun bila tertawa juga senang." (D)

Berdasarkan hasil observasi yang peneliti lakukan pada tanggal 20 Februari 2020 di MTsN 10 Agam tepatnya di dalam ruangan majelis guru ketika konseli mengikuti konseling perorangan, guru bimbingan dan konseling pada saat konseling perorangan berkomunikasi dengan konseli menggunakan bahasa yang tidak formal. Berdasarkan hasil wawancara dan observasi di atas dapat diketahui Intonasi yang digunakan guru bimbingan dan konseling dalam berkomunikasi dengan konseli dapat berubah-ubah. Seperti ketika marah guru bimbingan dan konseling akan sedikit memberi tekanan pada pengucapannya. Guru bimbingan dan konseling sekali-sekali terlihat mengkerutkan dahinya ketika berbicara dengan konseli dan menganggukkan kepala saat konseli berbicara. Guru bimbingan dan konseling juga terlihat mengelus pundak konseli sambil berbicara dengan konseli. Guru bimbingan dan konseling juga terlihat menggenggam tangan konseli sambil merangkul pundak konseli. Guru bimbingan dan konseling mencoba membuat suasana saat konseling perorangan tidak tegang dan santai.

Berkomunikasi, memahami dan berempati secara tepat. Bicara konselor yang terstruktur secara sistematis dan jelas akan menumbuhkan kepercayaan konseli untuk menyampaikan sesuatu yang sedang dirasakan dan dialaminya, namun hendaklah diiringi dengan pemahaman yang dalam serta empati (Taufik, 2012).

\section{Memahami}

Konselor perlu memahami apa yang konseli katakan dan mampu mengkomunikasikan pemahaman penyuluhan itu kepada konseli. Kesediaan konseli dalam proses konseling akan tergantung pada seberapa baik konselor dapat memahami konseli.

Berdasarkan hasil wawancara yang peneliti lakukan dengan guru bimbingan dan konseling tentang memahami konseli :

"Ibu tentunya dengan terbuka menerima konseli, kemudian sebagai guru bimbingan dan konseling kita harus dapat memahami konseli dengan secara keseluruhan serta menghilangkan persepsi negatif kita terhadap konseli."

Seiring dengan itu peneliti juga melakukan wawancara dengan konseli yang menyatakan bahwa : 
"Guru bimbingan dan konseling memperhatikan dan memahami saya dengan melihat-lihat dan memantau serta mencari informasi yang dibutuhkan." (F)

"Terkadang guru BK juga menanyakan kita ke teman-teman terdekat kita." (Z)

"Guru bimbingan dan konseling juga bisa memperhatikan dan menerima siswa melalui perantara diari, karena guru bimbingan dan konseling menerapkan membuat diari dengan mengisi curhatan atau persoalan yang kita alami ketika kita tidak ingin mengatakankannya secara langsung kepada guru bimbingan dan konseling." (P)

"Menurut saya, di kelas saat guru BK memberikan pelajaran maka guru BK akan melihat siswa dan meperhatian setiap tingkah laku siswa." (R)

"Bila kita melakukan suatu persoalan yang melanggar aturan maka kita akan diperhatikan dengan teliti oleh guru bimbingan dan konseling." (T)

"Saya juga tidak merasa terlalu diperhatikan oleh guru BK, karena saya termasuk siswa yang jarang untuk berkonsultasi pada BK" (S)

"Guru BK memperhatikannya dengan bertanya ketika ada yang di ragukan atau mendengar bila saya ada mengalami persoalan." (D)

Berdasarkan hasil observasi yang peneliti lakukan pada tanggal 24 Februari 2020 di MTsN 10 Agam tepatnya di dalam ruangan majelis guru ketika konseli mengikuti konseling perorangan, guru bimbingan dan konseling dapat memahami bagaimana karakteristis dari konseli. Guru bimbingan dan konseling berusaha untuk memahami konseli dengan memberikan respon yang sesuai pada pernyataan yang disampaikan oleh konseli. Berdasarkan hasil wawancara dan observasi di atas dapat diketahui ada beberapa informasi tentang siswa yang belum lengkap diketahui guru bimbingan dan konseling karena jumlah siswa yang banyak. Guru bimbingan dan konseling merasa banyak hal baru yang didapati dari pernyataan yang diutarakan oleh konseli.

Konselor menerima konseli (baik konseli yang self-referral maupun datang atas pengaruh pihak ketiga) secara terbuka, apa adanya, dengan prinsip KTSP, ramah dan lembut, sehingga konseli merasa dirinya diterima dalam suasana senyaman mungkin. Penampilan mimik, bahasa verbal dan non-verbal konselor yang mengajak dan bersahabat yang menciptakan suasana kondusif dan tanpapraduga dan tanpa-penilaian, akan membuat konseli merasa aman dan nyaman, merasa diterima, dan (lebih jauh) merasa kondisi dan kepentingan dirinya (akan) terakomondasikan (Prayitno, 2014).

\section{Berempati.}

Empati dapat diartikan sebagai kemampuan konselor untuk dapat merasakan dan menempatkan dirinya diposisi konseli. Hal ini akan terlihat jelas pada ekspersi wajah dan bahasa tubuh konselor. Contohnya ketika konseli merasa sedih, maka konselor bisa merasakan kesedihan konseli.

Berdasarkan hasil wawancara yang peneliti lakukan dengan guru bimbingan dan konseling tentang berempati :

"Tentu saja iya, apabila ibu memang pada waktunya berempati maka itu akan secara naluriah terlaksanakan. Ibu juga merasakan apa yang dirasakan konseli, saat 
konseli mengis ibupun merasakan sedih dan iba terhadap konseli. Ibu akan mengusap pundak konseli dan memberikan tisu untuk mengelap air mata konseli yang menangis."

Seiring dengan itu peneliti juga melakukan wawancara dengan konseli yang menyatakan bahwa :

"Guru BK menyesuaikan dengan situasi dan kondisi. Terkadang guru BK juga terlihat sedang marah. Saya merasakan bahwa guru BK peduli kepada saya karena guru BK selalu memperhatikan saya." (F)

"Guru BK juga peduli dengan saya, contohnya apabila ada persoalan guru BK selalu bertanya kepada saya. Guru BK juga memberikan rasa nyaman kepada saya." (Z)

"Guru BK berempati kepada saya dengan ikut memberika saya jalan atau solusi terhadap persoalan yang saya hadapi. Guru BK juga ikut mencari jalan keluar terhadap persoalan P." (P)

"Terkadang saya belum bisa mengetahui apakah guru BK juga merasakan apa yang di rasakan oleh saya." (R)

"Empati yang dilakukan oleh guru BK dengan cara memberikan dorongan yang baik dan memberikan informasi yang baik agar kita lebih mengerti." (T)

"Saya menganggap guru BK berempati dan peduli terhadap saya." (S)

"Saya merasa guru BK peduli dengan diri saya, karena guru BK juga ikut bersama-sama dengan saya mencari jalan keluar persoalan saya." (D)

Berdasarkan hasil observasi yang peneliti lakukan pada tanggal 24 Februari 2020 di MTs N 10 Agam tepatnya di dalam ruangan majelis guru ketika konseli mengikuti konseling perorangan guru bimbingan dan konseling ikut berempati kepada konseli seperti pada konseli yang menangis maka konselor akan berhenti sejenak untuk memberikan waktu menenangkan diri terhadap konseli sambil mengusap kepala konseli. Berdasarkan hasil wawancara dan observasi di atas dapat diketahui dengan adanya respon yang diberikan oleh guru bimbingan dan konseling tersebut konseli dapat merasa nyaman dengan guru bimbingan dan konseling serta konseli akan merasa bahwa guru bimbingan dan konseling dapat merasakan apa yang dirasakan konseli.

Berkomunikasi, memahami dan berempati secara tepat. Bicara konselor yang terstruktur secara sistematis dan jelas akan menumbuhkan kepercayaan konseli untuk menyampaikan sesuatu yang sedang dirasakan dan dialaminya, namun hendaklah diiringi dengan pemahaman yang dalam serta empati (Taufik, 2012).

\section{Menampilkan Kehangatan}

Berkaitan dengan kehangatan ada suatu sikap konselor yang menjadi landasan perilaku yaitu memancarkan perilaku peduli terhadap konseli. Mempunyai makna sebagai suatu kondisi yang ramah, peduli, dan dapat 
menghibur orang lain. Berdasarkan hasil wawancara yang peneliti lakukan dengan guru bimbingan dan konseling tentang menampilkan kehangatan :

"Ibu akan memanggil konseli dengan sebutan atau nama panggilan yang baik. Agar konseli merasa nyaman dengan guru bimbingan dan konseli sehingga dapat menciptakan kehangatan antara konselor dan konseli. konseli dapat terbuka kepada guru bimbingan dan konseling. ibu akan menerima konseli dengan terbuka sehingga konseli dapat merasakan kehangatan antara ibu dan konseli. "

Seiring dengan itu peneliti juga melakukan wawancara dengan konseli yang menyatakan bahwa :

"Kehangatan yang diberikan guru bimbingan dan konseling terlihat ketika guru bimbingan dan konseling tertawa lepas dengan saya. Saya juga mengatakan situasi yang sulit juga terjadi saat dimana guru bimbingan dan konseling selalu menanyai saya terus menurus yang membuat saya gugup." (F)

"Situasi bila guru BK akan marah bila saya melakukan kesalahan. Saya takut guru BK akan marah kepada saya." (Z)

"Situasi yang membuat kurang nyaman saat teman-teman saya datang ke ruangan konseling sehingga nantinya teman-teman mendengarkan apa yang saya bicarakan dengan guru BK." (P)

"Situasi yang ditakutinya adalah saat guru BK menanyakan permasalahan saya sedangkan saya terkadang takut untuk menceritakannya." (R)

"Saat guru BK menegur diri saya karena menyalahi aturan yang ada." (T)

"Situasi yang dialaminya saat konseling tidak ada kendala maka dari itu saya belum menemui kesulitan saat konseling." (S)

"Situasi yang di takuti yaitu saat orang lain datang dan mendengarkan apa yang sedang dibicarakan." (D)

Berdasarkan hasil observasi yang peneliti lakukan pada tanggal 26 Februari 2020 di MTs N 10 Agam tepatnya di dalam ruangan majelis guru ketika konseli mengikut konseling perorangan, guru bimbingan dan konseling sudah memperhatikan konseli, memberikan kehangatan dengan membimbing konseli dalam pemecahan persoalan konseli. Guru bimbingan dan konseling juga membantu konseli untuk mengentaskan persoalan yang sedang dialami konseli. Berdasarkan hasil wawancara dan observasi di atas dapat diketahui masih ada konseli yang belum terbuka kepada guru bimbingan dan konseling sehingga guru bimbingan dan konseling kesulitan dalam memberikan solusi kepada konseli. Konseli banyak diam dalam proses konseling membuat guru bimbingan dan konsling sulit menemukan pemecahan persoalan yang dialami konseli serta guru bimbingan dan konseling kesulitan dalam memahami konseli.

Kehangatan adalah kunci bagi tumbuhnya keakraban dan kepercayaan. Sikap dingin dan sinis akan dapat membuat konseli menjadi menjauhkan diri dari konselor, yang akhirnya tentu saja membuat konseli menjadi tidak terbuka (Taufik, 2012). Penampilan mimik, bahasa verbal dan non-verbal konselor yang 
mengajak dan bersahabat yang menciptakan suasana kondusif dan tanpa-praduga dan tanpa-penilaian, akan membuat konseli merasa aman dan nyaman, merasa diterima, dan (lebih jauh) merasa kondisi dan kepentingan dirinya akan terakomondasikan. Suasana penerimaan tersebut akan lebih terasa apabila lingkungan fisik tempat dilangsungkannya layanan konseling perorangan cukup mendukung. Luas ruangan, kondisi dan letak perabot, cahaya, udara dan aroma, serta asesoris pelengkap lainnya, semua itu perlu mendapat perhatian konselor (Prayitno, 2014).

\section{Menampilkan Keramahtamahan}

Keramahtamahan adalah kunci bagi tumbuhnya keakraban dan kepercayaan. Sikap dingin dan sinis akan dapat membuat konseli menjadi menjauhkan diri dari konselor yang akhirnya tentu saja membuat konseli menjadi tidak terbuka. Berdasarkan hasil wawancara yang peneliti lakukan dengan guru bimbingan dan konseling tentang menampilkan keramahtamahan:

"Keramahtamahan bisa dilihat dan dirasakan. Dirasakan dari nada bicara dan dilihat dari paras wajah. Keramahtamahan memang sangatlah penting dalam bimbingan dan konseling. Tentunya dengan mendengarkan, kemudian memperhatikan, fokus pada konseli, apabila ada rasanya sesuatu yang kurang pas bagi ibu, maka ibu akan langsung menannyakan pada konseli. Serta ramah tamah kepada semua konseli agar konseli merasa nyaman untuk melakukan proses konseling dengan konselor."

Seiring dengan itu peneliti juga melakukan wawancara dengan konseli yang menyatakan bahwa :

"Saya nyaman bila berbicara saat tidak memiliki suatu persoalan, namun ketika saya memiliki persoalan maka saya akan gelisah saat ingin mengungkapkannya."

(F)

"Saya nyaman dengan guru BK sehingga saya ketika bertemu guru BK tidak takut maupun gelisah." (Z)

"Terkadang adakalanya saya merasa nyaman, namun ada juga tidak. Saat di dalam ruangan ada teman-teman saya sehingga saya ragu-ragu untuk berbicara." (P)

"Saya merasa nyaman-nyaman saja. Karena saya merasa tidak ada yang perlu di cemaskan jika kita tidak merasa membuat suatu kesalahan." (R)

"Saat saya curhat dengan guru BK maka saya merasa nyaman. Namun bila saya ada persoalan saya tidak nyaman untuk memberitahukan kepada guru BK." (T)

"Saya merasa nyaman karena menurut saya guru BK menghargai kedatangan saya merasa didengarkan oleh guru BK." (S)

"Sudah nyaman bila hanya berdua saja dengan guru guru BK. Namun bila ramai maka membuat saya kurang nyaman." (D)

Berdasarkan hasil observasi yang peneliti lakukan pada tanggal 26 Februari 2020 di MTsN 10 Agam tepatnya di dalam ruangan majelis guru ketika konseli 
melakukan konseling perorangan, guru bimbingan dan konseling menampilkan sikap ramah kepada konseli. Guru bimbingan dan konseling menyambut konseli dengan tersenyum dan mempersilahkan konseli masuk ke ruangan untuk duduk. Berdasarkan hasil wawancara dan observasi di atas dapat diketahui ada saatnya guru bimbingan dan konseling menampilkan mimik wajah yang kesal terhadap konseli, yaitu tehadap konseli yang datang karena persoalan yang sama atau karena melakukan persoalan yang sama. Konseli tidak memperlihatkan perubahan dalam kehidupan sehari-hari sehingga guru bimbingan dan konseling merasa heran terhadap konseli.

Kesediaan konseli dalam proses konseling akan tergantung pada seberapa baik konselor dapat menerima konseli sebagaimana adanya secara positif. Dalam arti konselor tidak menuntut konseli tampil dengan kondisi, cara, sikap teretentu, dan tidak memberikan label-label tertentu pada konseli. Konselor meyakini dan tidak mempermasalahkan adanya perbedaan dengan konseli dalam beberapa hal, seperti perbedaan latar belakang, status ekonomi, usia, profesi, pendidikan, norma dan nilai-nilai yang dimiliki dan sebagainya.

Konselor yang dapat menerima konseli secara positif, dengan sikap ramah tamah, hangat dan penuh perhatian akan memberikan dampak positif kepada konseli. Konseli yang akan merasa bahwa dia benar-benar diterima, dipahami, diperhatiakn, dan merasa bahwa konselor benar-benar siap membantunya (Taufik, 2012).

\section{Membantu Konseli Mengenal Dirinya}

Konselor hendaklah mau membagi diri dan pengalaman-pengalaman tertentu yang sifatnya positif dan diperkirakan dapat dijadikan contoh oleh konseli. Banyak konseli yang tidak menyadari akan dirinya secara penuh. Konselor dapat membantu menunjukkan sesuatu yang terdapat dalam dirinya guna dimanfaatkan. Berdasarkan hasil wawancara yang peneliti lakukan dengan guru bimbingan dan konseling tentang membantu konseli mengenal dirinya :

"Ibu ingin membuat konseli sadar akan kemampuan yang dimilikinya dengan cara menumbuhkan kepercayaan diri yang dimiliki konseli bahwa setiap individu memiliki kelebihan masing-masing. Ibu akan menjelaskan kembali tentang asas kerahasiaan kepada konseli agar konseli dapat yakin dan percaya kepada guru BK, ibu akan mengajak konseli bertindak sesuai dengan aturan yang ada. Serta melihat minat dan bakat konseli dalam kehidupan sehari-hari."

Seiring dengan itu peneliti juga melakukan wawancara dengan konseli yang menyatakan bahwa :

"Guru BK selalu menyemangati siswanya untuk giat belajar. Saya merasa guru

BK membuat saya tidak bingung dalam mengetahui minat yang dimilikinya." (F)

"Guru BK memberikan inovasi kepada siswa nya dalam belajar." (Z)

"Guru BK memberikan informasi sekaligus dorongan dalam belajar." (P) 
"Guru BK memberikan nasehat kepada saya. Guru BK membantu membedakan yang baik dan buruknya. Bila ada yang saya tidak paham maka guru BK akan memberikan informasi kepada saya." (R)

"Menurut saya dengan cara guru BK memberikan informasi yang kita butuhkan agar kita menjadi pribadi yang lebih baik lagi. Guru BK juga mengingatkan kita pada hal-hal yang baik." (T)

"Guru BK secara langsung juga memberikan dorongan dan semangat kepada saya." (S)

"Guru BK dengan memberikan motivasi-motivasi yang membangun." (D)

Berdasarkan hasil observasi yang peneliti lakukan pada tanggal 28 Februari 2020 di MTsN 10 Agam tepatnya di dalam ruangan perpustakaan ketika konseli mengikuti konseling perorangan, guru bimbingan dan konseling memberikan berbagai macam informasi kepada konseli untuk menambah wawasan dan pengetahuan baru kepada konseli. Konseli juga dapat mengetahui minat dan bakatnya melalui layanan yang diberikan oleh guru bimbingan dan konseling. Berdasarkan hasil wawancara dan observasi di atas dapat diketahui guru bimbingan dan konseling berusaha memahami dimana kemauan dan minat konseli sehingga guru bimbingan dan konseling dapat tepat memberikan informasi kepada konseli sehingga konseli dapat mengenali dirinya dengan baik. Setelah konseli mengenal dirinya dengan baik maka konseli dapat menjalankan aktivitasnya dengan semangat tanpa terpaksa karena konseli sudah berada pada kondisi yang ia senangi.

Banyak konseli yang tidak menyadari akan dirinya secara penuh. Berbagai potensi positif yang sering kali tidak terlihat oleh konseli, dan hal-hal yang negatiflah pada diri dan lingkungannya yang selalu menonjol dimata dan dipikirannya sehingga menggangu hidupnya selama ini. Konselor membantu menunjukan sesuatu yang terdapat dalam dirinya dan orang lain guna dimanfaatkannya beserta berbagai sumber lain yang dapat didayagunakannya (Taufik, 2012).

\section{Dorongan dan Support}

Suatu usaha untuk menaikkan, mempertinggi dan memperhebat dorongan dalam diri konseli ketika memiliki kompetensi untuk bisa karena dukungan dari lingkungan sekitar, potensi, dan harapan yang realistik terhadap diri sendiri.

Berdasarkan hasil wawancara yang peneliti lakukan dengan guru bimbingan dan konseling tentang membantu konseli mengenal dirinya :

"Ibu akan melihat kemudian mengkelompokkan persoalannya, dan ibu akan memberikan penyuluhan, motivasi, mengajak lebih aktif dan berfikir positif serta memberikan pelayanan lebih lanjut yang dibutuhkan konseli. Konseli yang membutuhkan perhatian lebih akan ibu berikan dorongan serta motivasi yang dapat membuat konseli terpacu untuk ke arah yang lebih baik," 
Seiring dengan itu peneliti juga melakukan wawancara dengan konseli yang menyatakan bahwa :

"Guru BK selalu memiliki solusi jika saya memiliki masalah. saya senang dengan guru BK. Guru BK memberikan dorongan dengan memberikan motivasi yang saya butuhkan." (F)

"Bila ada persoalan saya bersama-sama dengan guru BK mencari jalan keluar yang baik. Sehingga saya merasa bersemangat untuk merubah sikapnya kearah yang lebih baik." (Z)

"Saya menyukai penampilan dari guru BK yang indah dipandang. Saya merasa semangat saat bertemu dengan guru BK." (P)

"Saya menyukai cara berbicara guru BK yang anggun yang dapat dipahami oleh siswa. Saya ingin guru BK bisa seperti teman bagi saya sehingga saya bisa leluasa berbicara dengan guru BK." (R)

"Guru BK memiliki ciri khasnya sendiri yang membuat berbeda dengan guru mata pelajaran lain. Sehingga saya lebih merasa nyaman dengan guru BK." (T)

"Yang saya senangi yaitu saya merasa diterima, kemudian didengarkan setiap kali saya mengutarakan isi hati saya." (S)

"Guru BK sangat perhatian kepada siswa, karena guru BK sangat mengetahui hal terbaru apa yang sedang terjadi di antara siswa." (D)

Berdasarkan hasil observasi yang peneliti lakukan pada tanggal 28 Februari 2020 di MTs N 10 Agam tepatnya di dalam ruangan majelis guru ketika konseli mengikuti konseling perorangan, guru bimbingan dan konseling memberikan motivasi serta semangat kepada konseli dalam kehidupan sehari-hari. Guru bimbingan dan konseling juga memberikan dorangan kepada konseli untuk belajar dengan sungguh-sungguh demi masa depan konseli. Berdasarkan hasil wawancara dan observasi di atas dapat diketahui guru bimbingan dan konseling memberikan informasi yang di butuhkan konseli dalam menumbuh kembangkan semangat konseli agar konseli dapat melakukan hal-hal yang positif di dalam kehidupannya sehari-hari. Guru bimbingan dan konseling juga berusaha menyemangati konseli untuk meraih masa depan yang baik.

Dalam melakukan sesuatu seringkali orang membutuhkan dorongan dari orang lain. Dorongan itu dapat menumbuhkan sikap optimis dalam pencapaiannya. Begitu juga halnya dengan konseli yang dibutuhkannya ialah dorongan konselor, sehingga barulah konseli bergerak untuk berbuat. Dalam hal ini dorongan dari konselor pada dasarnya dapat membuat konseli keluar dari masalah yang sedang dialaminya akan menumbuhkan keterbukaan konseli pada konselor (Taufik, 2012)

\section{Membantu Konseli}

Konselor harus memiliki kemampuan mengarahkan dan membantu konseli agar konseli dapat berpartisipasi secara penuh dalam proses konseling, dan mengikuti apa yang diminta atau diucapkan oleh konselor. Berdasarkan hasil 
wawancara yang peneliti lakukan dengan guru bimbingan dan konseling tentang membantu konseli:

"Sekolah juga menjalankan catatan siswa, dimana adanya poin terhadap peraturan yang dilanggar siswa. Maka secara tidak langsung akan dapat membantu guru BK dalam mengatasi persoalan yang sering ditemukan konseli."

Seiring dengan itu penulis juga melakukan wawancara dengan konseli yang menyatakan bahwa :

"Informasi yang diberikan oleh guru BK jelas dan dapat dimengerti siswa. Guru BK membantu saya bila menemukan persoalan." (F)

"Informasi yang diberikan oleh guru BK terkadang bukan informasi yang saya butuhkan. Saya terkadang belum merasa terbantu dengan informasi yang diberikan." (Z)

"Informasi yang diberikan oleh guru BK terkadang tidak sesuai dengan penilaiannya." (P)

"Saya terkadang kurang mendapatkan informasi yang saya butuhkan dari guru BK. karena jam mata pelajaran guru BK sangat singkat dari jam mata pelajaran lain." (R)

"Bila kita dekat dengan guru BK maka kita akan mudah untuk mendapatkan informasi dengan baik seperti hal yang tidak boleh dilakukan ataupun hal yang baik untuk dilakukan." (T)

"Informasi yang saya dapatkan lebih mudah untuk dimengerti karena guru BK menyampaikan dengan cara mudah untuk siswa dapat mengerti." (S)

"Sangat banyak diberikan informasi oleh guru BK, dari saya tidak tahu menjadi tahu." (D)

Berdasarkan hasil observasi yang peneliti lakukan pada tanggal 2 Februari 2020 di MTsN 10 Agam tepatnya di dalam ruangan perpustakaan ketika konseli mengikuti konseling perorangan, guru bimbingan dan konseling bersama-sama dengan konseli mencari jalan keluar dari persoalan konseli. Konseli menceritakan persoalan yang dialaminya kepada guru bimbingan dan konseling sehingga guru bimbingan dan konseling dapat mengetahui apa yang sedang dialami konseli. Berdasarkan hasil wawancara dan observasi di atas dapat diketahui bahwa keterampilan membantu konseli dilakukan guru bimbingan dan konseling sehingga dapat mencarikan jalan keluar dari persoalan yang dialami konseli dengan cara mengajak konseli berfikir untuk berubah ke arah yang lebih baik. Setelah konseli dapat membedakan perbuatan baik atau buruk terhadap dirinya maka guru bimbingan dan konseling meminta konseli untuk menerapkan hal baik pada diri konseli dan menjauhi hal yang berdampak buruk bagi diri konseli.

Membantu konseli bekerja mulai dari tahap awal permulaan konseling sampai masalah yang dialaminya betul-betul terentaskan menjadi kewajiban konselor bukan berarti konslelor harus selalu mengikuti konseli dalam melakukan usaha-usahanya melakukan kegiatan, namun konselor dapat melakukan tindakan 
pemantauan dan memberikan dorongan setiap kali konseli menyampaikan keberhasilannya (Taufik, 2012).

\section{KESIMPULAN}

Penelitian ini bertujuan untuk mengetahui tentang penerimaan konseling terhadap pelayanan konseling yang dirasakan. Berdasarkan hasil penelitian dapat disimpulkan dari beberapa aspek yang menjadi indikator penelitian, secara ratarata mendapatkan respon yang baik dari siswa. Pada aspek memperhatikan, guru BK memberikan perhatian penuh kepada siswa saat melaksanakn konseling perorangan, tidak hanya kepada konseli guru BK juga memberikan perhatian terhadap kenyamanan sarana dan prasarana konseling perorangan. Pada aspek mendengar, berdasarkan hasil penelitian seluruh informan setuju kemampuan mendengarkan guru BK sangat baik. Begitu pula dengan aspek menunda pendapat yang mengkritik, berkomunikasi, memahami, menampilkan kehangatan, menampilkan keramahtamahan, membantu konseli mengenal dirinya, dorongan dan support, serta aspek membantu konseli, seluruh informan menyatakan kemampuan guru BK pada kategori baik. Namun, hanya pada aspek berempati terdapat informan yang meragukan kemampuan guru BK untuk berempati kepada siswa. Berdasarkan temuan ini, peneliti memberikan saran kepada peneliti selanjutnya untuk melakukan penelitian lebih lanjut terkait dengan hal ini namun menggunakan metode lain seperti eksperimen.

\section{REFERENSI-REFERENSI}

Departemen Agama Republik Indonesia. (1989). Alquran dan Terjemahnya. Gema Risalah Press.

Gunawan, I. (2014). Metode Penelitian Kualitatif Teori Dan Praktik. Bumi Aksara.

Hanurawan, F. (2016). Metode Penelitian Kualitatif untuk Ilmu Psikologi. Raja Grafindo Persada.

Mappiare, A. T. A. (2008). Pengantar Konseling Dan Psikoterapi. Raja Grafindo Persada.

Margono. (2007). Metodologi Penelitian Pendidikan. Rineka Cipta.

Prayitno. (2014). L.1 - L.9. UNP Press.

Quthb, S. (2001). Tafsir Fi Zhilalil Qur'an Jilid 12. Gema Insani.

Suyanto, B., \& Sutinah. (2005). Metode Penelitian Sosial; Berbagai Alternative

Pendekatan. Kencana Prenada Media Group.

Taufik. (2012). Teknik Dan Laboratorium Konseling. UNP Press.

Willis, S. S. (2011). Konseling Individual (Teori dan Praktik). Alfabeta.

Yusri, F. (2019). Penguasaan Kompetensi Konselor Mahasiswa Peserta Program 
Pengalaman Lapangan (PPL) Prodi Bimbingan Konseling IAIN Bukittinggi. Jurnal Al-Taujih, 5(2), 183-195. 